\begin{tabular}{l} 
JOURNAL OF EMPOWERMENT \\
VOL. 2., No. 2, Desember 2021, h. 243-260 \\
ISSN 2580-0620 (Print) \\
ISSN 2597-9809 (Online) \\
Available Online at https://jurnal.unsur.ac.id/index.php/JE \\
\hline \hline
\end{tabular}

\title{
PEMBERDAYAAN MASYARAKAT BUDIDAYA MAGGOT BSF DALAM MENGATASI KENAIKAN HARGA PAKAN TERNAK
}

\section{EMPOWERMENT OF MAGGOT BSF CULTIVATION COMMUNITIES IN OVERCOMING THE INCREASE OF ANIMAL FEED PRICES}

\author{
Soni Maulana Ahmad, 2 Sulistyowati \\ ${ }^{12}$ Institut Agama Islam Negeri Kediri \\ boysout567@gmail.com, sulistyowatidiajeng@gmail.com
}

\begin{tabular}{|l|l|l|}
\hline Masuk: 03 September 2021 & Penerimaan: 04 Desember 2021 & Publikasi: 31 Desember 2021 \\
\hline
\end{tabular}

\begin{abstract}
ABSTRAK
Pandemi menghantam bidang ekonomi menjadikan semua harga komoditi naik. Kenaikan harga juga terjadi pada pakan ternak yang menjadikan produksi ayam dan ikan di Desa Pesing menurun. Fakultas Tarbiyah IAIN Kediri melaksanakan model Pengabdian Kepada Masyarakat yaitu Kuliah Keria Nyata (KKN) di Desa Pesing, Kecamatan Purwoasri, Kediri. Untuk mengatasi kenaikan harga pakan ternak, penulis memberikan solusi dengan penyuluhan mengenai pembudidayaan larva/ maggot lalat black soldier fly (BSF) sebagai alternatif pengganti pakan ternak yang lebih ekonomis. Pendekatan dalam pengabdian masyarakat ini termasuk pendekatan Participatory Action Research karena dilaksanakan partisipatif di antara masyarakat warga untuk mendorong terjadinya aksi transformatif. Hasil pengabdian berupa penyuluhan selama dua hari dengan hari pertama penyuluhan materi membuat media budidaya maggot dan hari kedua pemberian produk maggot jadi kepada peternak. Dengan alternatif pakan ternak berupa maggot BSF ini diharapkan produksi dapat meningkat. $\mathrm{Di}$ samping itu, diidentfikasi bahwa maggot BSF merupakan solusi penanganan sampah organik rumah tangga dan peluang bisnis.
\end{abstract}

Kata Kunci $\quad$ : Pengabdian; Maggot BSF; Pakan Ternak; KKN.

\begin{abstract}
The pandemic hit the economy, causing all commodity prices to rise. The Tarbiyah Faculty of IAIN Kediri implements the Community Service model, namely the Real Work Lecture (KKN) in Pesing Village, Purwoasri District, Kediri. To overcome the increase in animal feed prices, the author provides a solution by providing counseling about the cultivation of black soldier fly (BSF) larvae/maggots as an alternative to animal feed that is more economical. This approach in community service includes the Participatory Action Research approach. The results of the service were in the form of counseling for two days with the first day of material counseling making maggot cultivation media and the second day giving finished maggot products to farmers. With alternative animal feed, it is expected that production can increase. In addition, it was identified that the BSF maggot is a solution for handling household organic waste and a business opportunity.
\end{abstract}

Keywords $\quad:$ Service; BSF Maggot; Animal Feed; KKN.

\section{A. PENDAHULUAN}

Desa Pesing secara geografis terletak pada koordinat $7^{\circ} 40.3909^{\prime}$ Lintang Selatan dan $112^{\circ} 5.3547^{\prime}$ Bujur Timur. Desa Pesing merupakan salah satu desa di Kecamatan Purwoasri wilayah Kabupaten Kediri. Topografi ketinggian dataran rendah merupakan topografi desa ini yang membujur $51 \mathrm{~m}$ di atas permukaan laut. Wilayah Desa Pesing ini memiliki luas kurang lebih $239 \mathrm{Ha}$. Wilayah Desa 
Pesing ini dibagi dalam beberapa peruntukan untuk mendukung beberapa bidang, seperti fasilitas umum, permukiman warga, pertanian, perkebunan, dan lainnya. Desa Pesing sendiri terbagi menjadi 5 dusun yakni Dusun Pesing, Dusun Wonorenggo, Dusun Semanding, Dusun Gempol Payung, Dusun Magersari.

Desa Pesing memiliki potensi yang cukup beragam. Potensi yang teridentifikasi di desa ini antara lain terdapat pada bidang pertanian, perkebunan, dan peternakan. Pada sektor pertanian, tanah yang subur dan luas serta saluran irigasi yang memadai menjadi faktor yang sangat mendukung dalam perkembangan petani dalam mengelola sawah. Jenis tanaman yang ditanam berkutat pada padi, jagung, tebu dan sayur mayur. Untuk sektor perkebunan, terdapat pembudidayaan jambu dersono dan anggur. Pada sektor peternakan, terdapat pemain besar dan pemain kecil di desa ini dengan jenis ternak ayam, kambing, ikan lele dan ikan konsumsi lainnya.

Pada usaha peternakan yang akan dibahas dalam artikel ini, terdapat permasalahan yakni kenaikan harga pakan ternak. Ikan maupun ayam konsumsi memerlukan pakan ternak yang banyak sebelum bisa dipanen. Dengan kebutuhan pakan ternak yang tinggi, kenaikan harga pakan ternak ini menjadi penghambat dalam keberlangsungan usaha ternak di Desa Pesing.

Tahun 2020 menjadi tahun yang berat bagi masyarakat dunia dan Indonesia. Hal ini penulis rasakan mulai awal tahun yang banyak terjadi peristiwa-peristiwa yang menggemparkan. Bencana tersebut antara lain Trump yang mengakui pembunuhan jenderal Qasem Soleimani, ancaman perang sering terdengar, kebakaran hutan australia, Kobe Bryant meninggal dunia, indonesia dilanda banjir, konflik natuna dan banyak lagi.

Peristiwa menggemparkan tidak hanya berhenti di situ. Pada akhir 2019, dunia dihebohkan dengan kemunculan virus mematikan yang berasal dari hewan mamalia kelelawar. Virus itu dinamakan corona karena merupakan coronavirus jenis baru (SARS-CoV-2). Virus ini menggandeng dampak penyakit yang disebut coronavirus disease 2019 (COVID-19).

Kasus ini diumumkan ke khalayak umum pada 30 Januari 2020 oleh badan kesehatan nasional atau dalam bahasa inggris disebut sebagai World Health Organization (WHO). WHO mengumumkan ke publik bahwa COVID-19 menjadi darurat nasional bagi seluruh negara.(Guritno, 2021)

Awalnya, wabah virus corona ini muncul di salah satu kota di China yakni kota Wuhan. Virus ini diidentifikasi pada Desember 2019. Dikarenakan cara penularannya yang mudah yakni melalui droplet atau cairan, virus ini menyebar dengan cepat ke seluruh penjuru dunia termasuk di Indonesia.

Pada awalnya data menunjukkan $66 \%$ pasien yang terjangkit, berhubungan dengan salah satu pasar seafood atau pasar tradisional di Wuhan yag berada pada provinsi Hubei di Tiongkok.(Huang dkk., 2020, hlm. 1) Pada tanggal 11 Februari 2020, WHO memberi nama virus baru tersebut Severe acute respiratory syndrome coronavirus-2 (SARS-CoV-2). Virus ini menggandeng dampak penyakit yang disebut coronavirus disease 2019 (COVID-19).

Permulaan penularan virus ini belum dapat diidentifikasi sehingga banyak tenaga medis yang terjangkit dari pasiennya. Kasus penularan ini dikonfirmasi sebagai transmisi pneumonia atau infeksi yang menyebabkan peradangan pada paru paru antar manusia.

Kasus pasien konfrimasi Covid-19 di Indonesia bersumber dari suatu acara di kota Jakarta. Dalam acara tersebut, pasien kontak dengan warga negara asing (WNA) asli jepang namun bertempat tinggal di malaysia. Setelah melakukan kontak dengan WNA tersebut, pasien mengeluhkan suhu tubuh yang tinggi, batuk 
bahkan sesak nafas. Dalam waktu yang relatif singkat, virus ini menjadi pandemi (wabah penyakit global) yang menginfeksi sebagian besar wilayah dunia. Makhluk yang tidak lebih besar dari bakteri tersebut menggoncang segala sektor kehidupan.

Meskipun prosentase kematiannya lebih kecil dari prosesnase kesembuhannya, coronavirus ini tetaplah berbahaya. Virus ini berbahaya karena penularannya yang sangat mudah sehingga meskipun prosentasenya rendah namun cakupannya luas. Hingga saat ini berdasarkan update informasi yang disampaikan Satuan Tugas Penanganan COVID-19, pemerintah mencatat ada 4.043.736 kasus Covid19 di Tanah Air sejak diumumkan pertama kali pada 2 Maret 2020.(Maharani, 2021)

Secara umum, pandemi COVID-19 telah berdampak buruk pada ekonomi nasional mulai dari awal kemunculannya. Meskipun pada triwulan ketiga 2020 kondisi perekonomian Indonesia mulai membaik, laju pertumbuhan ekonomi nasional masih terhitung pertumbuhan negatif. Hal ini berpengaruh secara signifikan terhadap kenaikan barang di pasar indonesia termasuk pakan ternak.

Direktur Jenderal Perdagangan Dalam Negeri Kemendag Syailendra menyebutkan harga pakan telah naik 30 persen sejak pertengahan 2020 sampai saat ini. Hal ini juga tak lepas dari pergerakan rata-rata harga jagung lokal yang naik dari Rp3.845 per kg pada Januari 2021 menjadi Rp4.263 per kg. Beliau menyebutkan kontribusi jagung pada pakan unggas setidaknya berada di kisaran 40 sampai 45 persen. Pakan juga menjadi salah satu kontributor terbesar dalam struktur produksi ayam broiler.

Naiknya harga pakan juga berlaku pada pakan ikan. Kenaikan pakan ikan ini menjadi kendala bagi pembudidaya ikan. Padahal, ikan konsumsi untuk saat ini bisa menunjang ketahanan pangan. Pembudidaya ikan lele di Desa Pesig, Kecamatan Purwoasri, Kediri, Faruk Rumaja Asri mengatakan, harga pakan ikan mengalami kenaikan sejak 1,5 bulan lalu. Bahkan selama 1,5 bulan terakhir itu harga pakan ikan naik dua kali. Untuk pakan ikan lele harganya saat ini antara $\mathrm{Rp} 310$ ribu sampai $\mathrm{Rp} 345$ ribu.

Mengingat harga pakan ternak terutama ikan yang tinggi, penulis mencoba memberikan solusi dengan pembudidayaan maggot BSF. Maggot yang merupakan larva lalat Black Soldier Fly (BSF) memang sangat istimewa dibandingkan bahan baku pakan alternatif lainnya karena mengandung nutrien yang lengkap untuk ikan maupun ayam dengan kualitas yang baik. Selain itu, Maggot bisa diproduksi dalam waktu singkat dan berkesinambungan dengan jumlah yang cukup untuk memenuhi kebutuhan pakan ikan.

Keunggulan lainnya, yaitu masyarakat mudah mengadopsi teknologi produksi Maggot. Kemudian, dalam prosesnya Maggot juga bisa diproduksi menjadi tepung (mag meal), sehingga bisa menekan biaya produksi pakan.

Maggot BSF dalam proses budidayanya juga dapat diberikan pakan berupa sampah organik. Sampah organik rumah tangga seperti sisa buah buahan, sayuran maupun sisa makanan lain memang merupakan makanan bagi larva lalat black soldier fly ini. Dengan kebutuhan maggot untuk mengkonsumsi sisa ataupun sampah organik rumah tangga ini menjadikan budidaya maggot BSF termasuk sebagai upaya pengendalian sampah organik. Pengolahan sampah organik melalui teknologi biokonversi Maggot diharapkan juga berperan dalam mengurangi sampah organik dengan cepat serta dapat menciptakan lapangan pekerjaan baru dan juga ketersediaan Maggot sabagai bahan baku alternatif pakan tersedia sepanjang waktu. 
Di sisi lain, pengembangan Maggot sebagai bahan baku alternatif pakan ikan, dipastikan akan menghadapi banyak tantangan. Sehingga butuh ketekunan dan edukasi kepada masyarakat terkait sampah organik. Melihat potensinya yang banyak itu, penulis memberdayakan masyarakat Desa Pesing melalui penyuluhan mengenai pembudidayaan maggot BSF ini.

Program pemberdayaan ini termasuk dalam program kegiatan yang disusun dalam kegiatan kuliah kerja nyata (KKN) IAIN Kediri. KKN adalah mata kuliah praktik yang bertujuan untuk melatih dan membekali mahasiswa menerapkan ilmu, belajar memecahkan berbagai persoalan yang terjadi di masyarakat, mengembangkan potensi masyarakat dan mempunyai sikap keberpihakan kepada masyarakat kecil, lemah, atau terpinggirkan.

Pada masa pandemi COVID-19 saat ini, format pelaksanaan pengabdian masyarakat berbeda dengan beberapa tahun sebelumnya. Merujuk Keputusan Direktur Jendral Pendidikan Islam Nomor 3394 Tahun 2020 Tentang Petunjuk Teknis Kuliah Kerja Nyata Masa Wabah Corona Virus Disease 2019 (COVID-19), bahwa Kuliah Kerja Mahasiswa dapat dilakukan dari rumah masing-masing. Kuliah Kerja Nyata Dari Rumah (KKN-DR) merupakan salah satu mata kuliah yang wajib diikuti oleh seluruh mahasiswa IAIN Kediri, dengan bimbingan Dosen Pembimbing Lapangan (DPL). Model Kuliah Keria Nyata Dari Rumah (KKN-DR) mengharuskan mahasiswa melakukan pengabdian masyarakat dari rumah (tempat tinggal) mereka masing-masing dengan membuat layanan-layanan pengabdian masyarakat dalam memberikan penguatan dan kesadaran serta kepedulian terhadap pandemi COVID-19, relasi kesehatan dengan ibadah, pendidikan, dakwah keagamaan Islam, teknologi tepat guna dan kebutuhan masyarakat yang sesuai dengan keilmuan masing-masing program studi, dengan berbasiskan hasilhasil riset sebelumnya atau riset yang sedang berkembang/berlangsung.(IAIN Kediri, 2021, hlm. 1)

Maka, dalam artikel ini penulis memaparkan mengenai teknis pemberdayaan masyarakat dengan pembudidayaan maggot lalat black soldier fly dan analisa dalam pengaplikasiannya untuk pengganti maupun pendukung pakan ternak di Desa Pesing.

\section{B. METODE}

Pengabdian kepada masyarakat ini dilakukan di Desa Pesing, Kecamatan Purwoasri Kabupaten Kediri dengan memanfaatkan fasilitas balai desa Pesing dan mengambil satu dusun untuk tempat penyuluhan dan pengaplikasian produk jadi. Program pemberdayaan masyarakat ini merupakan bagian dari rangkaian kegiatan KKN yang dimulai sejak hari Senin tanggal 05 Juli 2021 sampai hari Rabu tangal 18 Agustus 2021. Pendekatan dalam pengabdian masyarakat ini termasuk kedalam pendekatan Participatory Action Research karena dilaksanakan secara partisipatif di antara masyarakat warga dalam suatu komunitas atau lingkup sosial yang lebih luas untuk mendorong terjadinya aksi-aksi transformatif (perubahan kondisi hidup yang lebih baik. Kegiatan pemberdayaan masyarakat ini dimulai dengan tahap persiapan, survey harga pakan ternak ayam dan ikan, pembelian bahan media maggot, pembelian maggot jadi, pelaksanaan penyuluhan pertama mengenai pembuatan media budidaya maggot, penyuluhan kedua mengenai aplikasi maggot yang telah siap pakai, evaluasi dan pelaporan hasil kegiatan.

Persiapan kegiatan pengabdian meliputi musyawarah dengan kepala desa Pesing, karang taruna dan koordinasi dengan kepala dusun - kepala dusun yang ada di desa Pesing untuk pelaksanaan kegiatan pengabdian. Untuk memecahkan 
masalah mengenai kenaikan harga pakan ternak yang dihadapi dalam kegiatan pengabdian ini maka dirancang kegiatan yang terstruktur mulai dari perizinan dengan perangkat desa sampai survei harga. Survei harga pakan dilakukan di penjual pakan ternak di sekitar desa pesing. Untuk persiapan bahan media maggot dipersiapkan bekerjasama dengan mahasiswa yang $\mathrm{KKN}$ di tempat yang sama sekaligus mengkondisikan teknis penyuluhan dengan peternak dan pembudidaya ikan setempat.

\section{HASIL ATAU PEMBAHASAN \\ 1. Pengabdian Masyarakat}

Menurut Direktorat Riset dan Pengabdian Masyarakat Universitas Indonesia, pengabdian kepada masyarakat atau kegiatan pengabdian kepada masyarakat adalah kegiatan yang mencakup upaya-upaya peningkatan kualitas sumber daya manusia antara lain dalam hal perluasan wawasan, pengetahuan maupun peningkatan keterampilan yang dilakukan oleh civas akademika sebagai perwujudan dharma bakti serta wujud kepedulian untuk berperan aktif meningkatkan kesejahteraan dan memberdayakan masyarakat luas terlebih bagi masyarakat ekonomi lemah.(Direktorat Riset Pengabdian kepada Masyarakat Universitas Indonesia, 2011 , hlm. 4)

Pengabdian adalah pengamalan IPTEKS (Ilmu Pengetahuan, Teknologi dan Seni) yang dilakukan oleh perguruan tinggi secara melembaga melalui metode ilmiah langsung kepada masyarakat (di luar kampus yang tidak terjangkau oleh program pendidikan formal) yang membutuhkannya, dalam upaya mensukseskan pembangunan dan mengembangkan manusia pembangunan.

Pengabdian kepada Masyarakat juga merupakan salah satu Tri Dharma Perguruan Tinggi. Oleh karena itu peran dosen dan mahasiswa sebagai leader of change akan lebih terasa tatkala mengabdikan dirinya untuk masyarakat.

Pengabdian kepada Masyarakat dapat diartikan juga sebagai respons akademik masyarakat kampus atas kebutuhan, tantangan atau persoalan yang dihadapi masyarakat, baik secara langsung maupun tidak langsung. Jika demikian halnya, maka Pengabdian kepada Masyarakat tidak harus diartikan sempit dengan fokus pada kegiatan yang mengarah kepada masyarakat miskin semata. Oleh karena itu, arti dan makna Pengabdian kepada Masyarakat menjadi lebih luas dengan meliputi seluruh strata sosial masyarakat.

Misi Pengabdian kepada Masyarakat sendiri adalah menciptakan peradaban dan nilai-nilai kehidupan baru bagi masyarakat luas dan juga masyarakat kampus. Dengan demikian, prinsip transfer ilmu pengetahuan dan teknologi dapat terpenuhi. Sebab ada solusi mengalir dari kampus-kampus dan sebagai imbalannya, tantangan mengalir masuk dari masyarakat. Mengacu kepada misi Pengabdian kepada Masyarakat tersebut ditetapkan aliran kerja bagi masyarakat dosen yang berniat melakukan Pengabdian kepada Masyarakat. Aliran kerja tersebut diawali dengan kunjungan ke masyarakat sasaran sesuai dengan jenis program Pengabdian kepada Masyarakat yang akan diusulkan.

Pada saat kunjungan, pengusul sebaiknya tidak mengidentifikasi sekaligus menetapkan persoalan, kebutuhan atau tantangan yang dihadapi masyarakat secara sepihak. Akan tetapi, hasil identifikasi Perguruan Tinggi harus dibicarakan terlebih dahulu bersama masyarakat dan mendengarkan serta mencernakan masukan-masukan yang diberikan berkenaan dengan hal tersebut. Masukan yang berasal dari masyarakat menjadi pekerjaan utama atau kegiatan yang diprioritaskan pada usulan Pengabdian kepada Masyarakat. Hal inilah yang selanjutnya menjadi pemikiran dosen untuk dicarikan solusinya. Tindakan- tindakan 
yang dilakukan dalam kegiatan Pengabdian kepada Masyarakat umumnya diwadahi dalam satu atau beberapa program.(Shodiq, 2013, hlm. 23-25)

Pengabdian kepada masyarakat merupakan salah satu bentuk Tridharma Perguruan Tinggi disamping pendidikan dan penelitian. Sejak awal gagasan pendirian perguruan tinggi adalah mengembangkan ilmu pengetahuan, mempersiapkan warga negara yang cerdas, berilmu, beriman, dan beramal untuk kemajuan bangsa, serta berkhidmat kepada masyarakat yang ada. Semangat keutuhan atau integrasi Tridharma ini dimandatkan melalui Undang-undang no. 12 tahun 2012. Dalam UU ini pengabdian pada masyarakat diartikan sebagai kegiatan sivitas akademika yang memanfaatkan ilmu pengetahuan dan teknologi untuk memajukan kesejahteraan masyarakat dan mencerdaskan kehidupan bangsa.(Satriya P. K.W, 2013, hlm. 10)

Sampai saat ini, berdasarkan Tipologi Pengabdian Norton ditengarai ada tiga paradigma, cara pandang dan model pengabdian kepada masyarakat.(Bringle dkk., 2006, hlm. 5-15) Paradigma ini merupakan kerangka umum pemikiran dan asumsi-asumsi yang mempengaruhi dan dipengaruhi oleh nilai-nilai dan perilaku masyarakat baik lokal atau global pada masanya. Paradigma pertama dikenal dengan nama Charity (bakti Sosial atau sedekah). Asumsi dari pemikiran ini adalah bahwa kampus merupakan pihak yang punya sumber daya pengetahuan dan teknologi dan karena itu berkewajiban untuk memberikannya atau mensedekahkannya kepada masyarakat yang dianggap sebagai pihak yang tidak punya dan selalu dalam keadaan membutuhkan uluran tangan perguruan tinggi. Kegiatan-kegiatan model pengabdian ini seringkali bersifat sporadis dan berupa santunan makanan, pakaian, dan alat-alat rumah tangga. llustrasi anekdot untuk paradigma ini adalah memberi ikan kepada orang yang lapar.

Paradigma kedua adalah Project (Proyek). Asumsi-asumsi dasar dalam paradigma ini adalah bahwa pengabdian harus dilakukan dengan cara yang terorganisir. Oleh karena itu, model pengabdian ini diawali dengan kajian masalah yang dihadapi oleh masyarakat, menentukan solusi, merencanakan tindakan, dan menerapkan rencana untuk mencapai tujuan yang ditetapkan. Pengabdian seperti ini seringkali mengabaikan peran masyarakat sebagai unsur yang paling berkepentingan dalam proyek lantaran mereka dianggap bukan sebagai ahli atau orang yang terlatih. Oleh karena itu, masyarakat dinilai membutuhkan pelatihan-pelatihan keterampilan beserta penguasaan teknologinya. Ungkapan anekdot untuk paradigma ini adalah "jangan kasih ikan orang yang lapar tapi beri pancing dan cara menggunakannya." Ungkapan ini terkesan mengkambinghitamkan (blaming the victims) masyarakat atas ketidakberuntungannya dan sesekali malah menciptakan jenis ketergantungan baru.

Paradigma ketiga biasa disebut dengan Social Change (Transformasi Sosial). Ini adalah paradigma yang menyakini nilai-nilai keadilan dan kearifan lokal. Pengabdian ini menitikberatkan pada proses pengembangan hubungan intramasyarakat sebagai satu kesatuan warga yang setara dan dengan pemangku kepentingan lainnya secara proporsional. Penciptakan lingkungan pembelajar secara kolektif dan kolaboratif adalah bentuk dari kegiatan pengabdian ini. Masyarakat dipandang sebagai satu unit komunitas yang mempunyai kuasa dan kendali atas asset, sumber daya, dan masalahnya sendiri. Dalam paradigma ini juga, masyarakat dianggap punya sesuatu, yaitu power (kekuatan dan kekuasaan) yang acapcali kurang atau tidak berkembang. Oleh karena itu, kegiatan- kegiatan pengabdian dalam paradigma ini bersifat empowering (pemberdayaan) yang berkelanjutan (sustainable) dan menyertakan nilai-nilai 
democratic governance untuk berbagi kekuasaan dengan adil dalam masyarakat. Fokus dari pengabdian ini terletak pada pemanfaatan dan pemeliharaan sumber daya masyarakat beserta penyediaan akses yang merata untuk semua lapisan masyarakat. Bukan sekedar ikan, pancing dan keterampilannya yang menjadi konsentrasi melainkan sungai (ruang), ekosistem dan ekologi yang sehat dimana ikan bisa hidup dan dimanfaatkan.

Ketiga paradigma di atas bisa dipahami sebagai satu kontinum, artinya satu sama lain tidak perlu dipertentangkan. Adakalanya satu paradigma dan model pengabdian kepada masyarakat tepat untuk dipakai dalam konteks-konteks tertentu. Hal yang paling penting dari masing-masing paradigma itu adalah integritas antara niat baik dan tindakan pengabdian yang sesuai dengan konteks dan bermuara pada terciptanya pola hubungan yang adil dan setara dari berbagai aspek, seperti gender, lingkungan, budaya, sosial, dan politik.

\section{Participatory Action Research (PAR)}

PAR Pada awalnya dikembangkan oleh seorang psikolog bernama Kurt Lewin di awal hingga pertengahan 1900an. Freire kemudian mengembangkan PAR sebagai kritik atas model pendidikan tradisional dimana guru berdiri di depan dan memberikan informasi ke murid sebagai penerima pasif. PAR ini juga merupakan kritikan terhadap penelitian yang lazimnya dilakukan oleh universitas maupun pemerintah dimana para ahli datang ke komunitas dan mempelajari subjek penelitian kemudian pergi membawa data untuk ditulis dalam laporan maupun tulisan.(IAIN Kediri, 2021, hlm. 79-84)

Participatory Action Research (PAR) adalah metode riset yang dilaksanakan secara partisipatif di antara warga masyarakat dalam suatu komunitas aras bawah yang semangatnya untuk mendorong terjadinya aksi-aksi transformatif melakukan pembebasan masyarakat dari belenggu ideologi dan relasi kekuasan (perubahan kondisi hidup yang lebih baik). Dengan demikian, sesuai istilahnya PAR memiliki tiga pilar utama, yakni metodologi riset, dimensi aksi, dan dimensi partisipasi. Artinya, PAR dilaksanakan dengan mengacu metodologi riset tertentu, harus bertujuan untuk mendorong aksi transformatif, dan harus melibatkan sebanyak mungkin masyarakat warga atau anggota komunitas sebagai pelaksana PAR-nya sendiri.

PAR merupakan kegiatan riset yang berbeda dengan metode penelitian ilmiah lainnya yang biasa dilakukan oleh para akademisi, lembaga survey, dll. Di dalam metode penelitian ilmiah pada umumnya seorang researcher menjadikan suatu kelompok masyarakat hanya sebagai objek yang diteliti untuk mendapatkan suatu inti permasalahan tanpa memberikan perubahan (transformasi) nilai di dalam suatu masyarakat tersebut.

Di dalam kegiatan PAR, peneliti/praktisi PAR tidak memisahkan diri dari situasi masyarakat yang diteliti, melainkan melebur ke dalamnya dan bekerja bersama warga dalam melakukan PAR. PAR membahas kondisi masyarakat berdasarkan sistem makna yang berlaku di situ, bukan menurut disiplin ilmu tertentu di luar budaya masyarakat tersebut. PAR tak bisa lagi berposisi "bebas nilai" dan tidak memihak seperti yang dituntut ilmu pengetahuan sebagai syarat obyektivitas, melainkan harus memihak pada kelompok yang lemah, miskin, dirugikan, dan menjadi korban. Selain itu, PAR tidak berhenti pada publikasi hasil riset (laporan) dan rekomendasi untuk riset berikutnya, melainkan berorientasi pada perubahan situasi, peningkatan pengetahuan dan kemampuan masyarakat warga untuk memahami dan mengubah situasi mereka menjadi lebih baik. 
Setiap kegiatan PAR bertujuan :1) Untuk membangun kesadaran masyarakat atau memberdayakan masyarakat aras bawah melalui pendidikan kritis, pembelajaran orang dewasa, dialog public, dll; 2) Untuk merubah cara pandang tentang penelitian dengan menjadikan penelitian sebuah proses partisipasi; 3) Untuk menggeser padarigma: masyarakat sebagi Objek menjadi Subjek penelitian; dan 4) Untuk membawa perubahan (transformation) nilai sosial di masyarakat.PrinsipPrinsip PAR terbagi menjadi 4 (empat) prinsip yaitu :1) Prinsip Partisipasi prinsip ini mengharuskan PAR dilaksanakan separtisipatif mungkin, melibatkan siapa saja yang berkepentingan dengan situasi yang sedang diteliti dan perubahan kondisi yang lebih baik. Dengan prinsip ini, PAR dilakukan bersama di antara warga masyarakat melalui proses berbagi dan belajar bersama, untuk memperjelas dan memahami kondisi dan permasalahan mereka sendiri. Prinsip ini juga menuntut penghargaan pada setiap perbedaan yang melatarbelakangi warga saat terlibat dalam PAR, termasuk penghargaan pada kesetaraan jender (terlebih jika dalam suatu komunitas warga perempuan belum memperoleh kesempatan yang setara dengan laki-laki untuk berpartisipasi sosial). Berbeda dengan riset konvensional, tim peneliti dalam PAR bertindak sebagai fasilitator terjadinya proses riset yang partisipatif di antara warga, bukan tim peneliti yang meneliti kondisi komunitas dari luar sebagai pihak asing; 2) Prinsip Orientasi Aksi prinsip ini menuntut seluruh kegiatan dalam PAR harus mengarahkan masyarakat warga untuk melakukan aksi-aksi transformatif yang mengubah kondisi sosial mereka agar menjadi semakin baik. Oleh karena itu, PAR harus memuat agenda aksi perubahan yang jelas, terjadwal, dan konkret; 3) Prinsip Triangulasi harus dilakukan dengan menggunakan berbagai sudut pandang, metode, alat kerja yang berbeda untuk memahami situasi yang sama, agar pemahaman tim peneliti bersama warga terhadap situasi tersebut semakin lengkap dan sesuai dengan fakta. Setiap informasi yang diperoleh harus diperiksa ulang lintas kelompok warga/elemen masyarakat (crosscheck). Prinsip ini menuntut PAR mengandalkan data-data primer yang dikumpulkan sendiri oleh peneliti bersama warga di lapangan. Sedangkan data- data sekunder (riset lain, kepustakaan, statistik formal) dimanfaatkan sebagai pembanding; dan 4) Prinsip Luwes atau Fleksibel, meskipun PAR dilakukan dengan perencanaan sangat matang dan pelaksanaan yang cermat atau hati-hati, peneliti bersama warga harus tetap bersikap luwes menghadapi perubahan situasi yang mendadak, agar mampu menyesuaikan rencana semula dengan perubahan tersebut. Bukan situasinya yang dipaksa sesuai dengan desain riset, melainkan desain riset yang menyesuaikan diri dengan perubahan situasi.

Adapun metode dan alat kerja PAR Secara umum, metode PAR terbagi dalam dua tipe, yakni Eksplanatif dan Tematik. PAR Eksplanatif memfasilitasi komunitas/masyarakat untuk berpartisipasi dalam menganalisis kebutuhan, permasalahan, dan solusinya sebelum merencanakan aksi transformatif. Sedangkan PAR Tematik menganalisis program aksi transformatif yang sudah berjalan, sebagai alat evaluasi dan pengamatan (monitoring). Dengan memanfaatkan kekayaan riset-riset konvensional yang masih terus berkembang, PAR melengkapi diri dengan banyak metode dan alat kerja. Untuk mengumpulkan data lapangan dan menganalisisnya, PAR memiliki metode berbagi cerita (sharing), wawancara mendalam (in-depth interview) dan diskusi kelompok terfokus (focus group discussion/FGD). Dalam FGD misalnya, partisipan atau informan tidak sebatas berdiskusi dalam posisi duduk, melainkan bisa berdiskusi dalam dinamika tertentu dengan menggunakan alat kerja tertentu, misalnya pemetaan gagasan (mind mapping), diagram pohon masalah (problem tree), grafik kecenderungan 
(trend lines), matriks peringkat atau skala prioritas (ranking), dsb. Bahkan, penggalian informasi dari partisipan bisa dilakukan melalui permainan peran (role-play). Dalam dinamika tersebut, partisipan/informan berpeluang lebih besar mengungkapkan pengalaman, gagasan, dan refleksi mereka secara lebih terbuka karena terbantu dengan sejumlah alat kerja yang memudahkan pengamatan (visual) dan kegiatan yang dinamis/tidak kaku. Dinamika tersebut juga memudahkan fasilitator untuk mendorong sebanyak mungkin partisipan/informan berpartisipasi lebih aktif karena menggunakan kegiatan dan alat kerja yang bisa dipilih atas dasar kesesuaiannya dengan latar belakang budaya, pendidikan, dan pekerjaan partisipan/informan. Adapun tahapan kegiatan PAR :

a) Perencanaan: Membuat kelompok PAR; Membuat rencana PAR; Pemetaan Wilayah; Membuat analisa awal kasus komunitas atau membuat LO awal; Mencari Kontak; Menyusun Strategi; Mempersiapkan fisik yang prima; dan Penyiapan Logistic yang memadai (ID Card, akomodasi yang cukup, alatalat penelitian);

b) Pelaksanaan: Turun ke komunitas/lapangan dan live in; Mendekati kontak atau membangun sekutu strategis; Pengumpulan data (wawancara, observasi, dII); Membuat legal opinion atau analisa kasus struktural; dan Menyusun rencana aksi;

c) Evaluasi: Melakukan evaluasi PAR keseluruhan;

d) Daur Program dan Tahap Pelaksanaan

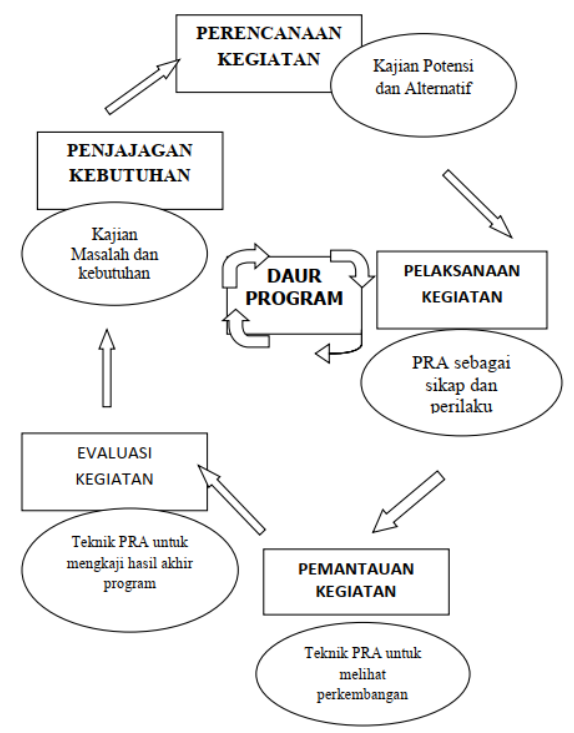

Gambar 1. Daur Program KKN PAR

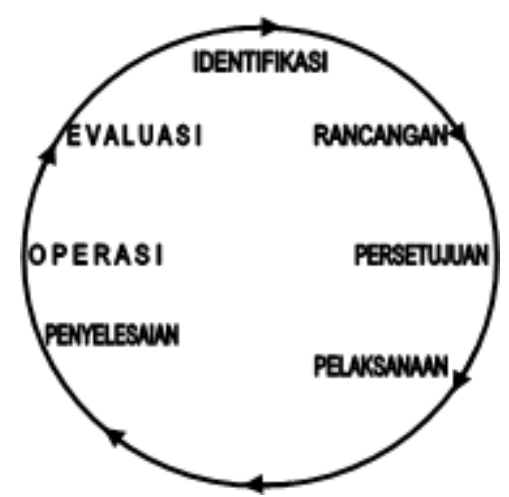

Gambar 2. Tahap Pelaksanaan KKN PAR 


\section{Budidaya Maggot BSF}

Black Soldier Fly (BSF) atau dalam bahasa latin Hermetia illucens merupakan spesies lalat dari ordo Diptera, family Stratiomyidae dengan genus Hermetia. BSF merupakan lalat asli dari benua Amerika dan sudah tersebar hampir di seluruh dunia. Hem (2011) menyatakan BSF juga ditemukan di Indonesia, tepatnya di daerah Maluku dan Irian Jaya sebagai salah satu ekosistem alami BSF. Suhu optimum pertumbuhan BSF adalah antara $30^{\circ} \mathrm{C}-36^{\circ} \mathrm{C}$. Larva BSF tidak dapat bertahan pada suhu kurang dari $7^{\circ} \mathrm{C}$ dan suhu lebih dari $45^{\circ} \mathrm{C}$. (Hem, 2011 , hlm. 9)

BSF adalah spesies lalat tropis yang mempunyai kemampuan mengurai materi organik dengan sangat baik dan sudah digunakan sebagai agen pengurai limbah organik. BSF mampu mengekstrak energi dan nutrien dari sisa sayuran, sisa makanan, bangkai hewan, dan sisa kotoran lainnya seperti tinja dan air limbah domestik sebagai makanannya. Rendahnya nilai ekonomis dari limbah tersebut menguntungkan upaya pengembangan bioteknologi dari BSF. Larva dari BSF dapat mendaur ulang sampah jenis padat maupun jenis cairan, serta cocok untuk dikembangbiakkan secara monokultur karena mudah disebarkan, aman dan mudah dikembangbiakkan di semua kondisi, tidak mudah terpengaruh oleh mikroorganisme, dan tidak mudah teriangkit parasit.(Holmes dkk., 2012, hlm. 971) BSF juga mampu bertahan dalam kondisi ekstrem dan mampu bekerjasama dengan mikroorganisme untuk mendegradasi sampah organik. BSF bukan hama dan merupakan jenis lalat yang memiliki risiko penyebaran penyakit yang lebih rendah dibanding jenis lalat lainnya.(Diener dkk., 2011, hlm. 358)

Siklus hidup BSF merupakan sebuah siklus metamorfosis sempurna dengan 4 (empat) fase, yaitu telur, larva, pupa, dan BSF dewasa. Siklus metamorfosis BSF berlangsung dalam rentang kurang lebih 40 hari, tergantung pada kondisi lingkungan dan asupan makanannya.(Alvarez, 2012, hlm. 8-10)

a. Fase Telur. Lalat betina BSF mengeluarkan sekitar 300-500 butir telur pada masa satu kali bertelur. BSF meletakkan telurnya di tempat gelap, berupa lubang/celah yang berada di atas atau di sekitar material yang sudah membusuk seperti kotoran, sampah, ataupun sayuran busuk. Telur BSF berukuran sekitar 0.04 inci (kurang dari $1 \mathrm{~mm}$ ) dengan berat 1-2 $\mu \mathrm{g}$, berbentuk oval dengan warna kekuningan.Telur BSF bersifat agak lengket dan sulit lepas meskipun dibilas dengan air. Suhu optimum pemeliharaan telur BSF adalah antara $28-35^{\circ} \mathrm{C}$. Pada suhu kurang dari $25^{\circ} \mathrm{C}$ telur akan menetas lebih dari 4 hari, bahkan bisa sampai 2 atau 3 minggu. Telur akan mati pada suhu kurang dari $20^{\circ} \mathrm{C}$ dan lebih dari $40^{\circ} \mathrm{C}$. Telur BSF akan matang dengan sempurna pada kondisi lembab dan hangat, dengan kelembaban sekitar 30\%-40\%. Telur akan menetas dengan baik pada kelembaban $60 \%-80 \%$. Jika kelembaban kurang dari $30 \%$, telur akan mengering dan embrio di dalamnya akan mati. Kondisi ini akan memicu pertumbuhan jamur jenis Ascomycetes yang dapat mempercepat kematian telur lainnya sebelum menetas menjadi larva. Telur BSF juga tidak dapat disimpan di tempat yang miskin oksigen ataupun terpapar pada tingkat gas karbondioksida yang cukup tinggi.

b. Fase Larva. Larva yang baru menetas dari telur berukuran sangat kecil, sekitar 0.07 inci $(1.8 \mathrm{~mm})$ dan hampir tidak terlihat dengan mata telanjang. Tidak seperti lalat dewasa yang meyukai sinar matahari, larva BSF bersifat photofobia. Hal ini terlihat jelas ketika larva sedang makan, dimana mereka lebih aktif dan lebih banyak berada di bagian yang miskin cahaya. Larva yang baru menetas optimum hidup pada suhu $28-35^{\circ} \mathrm{C}$ dengan kelembaban 
sekitar $60-70 \%$. Pada umur 1 (satu) minggu, larva BSF memiliki toleransi yang jauh lebih baik terhadap suhu yang lebih rendah. Ketika cadangan makanan yang tersedia cukup banyak, larva muda dapat hidup pada suhu kurang dari $20^{\circ} \mathrm{C}$ dan lebih tinggi daripada $45^{\circ} \mathrm{C}$. Namun larva BSF lebih cepat tumbuh pada suhu $30-36^{\circ} \mathrm{C}$. Larva yang baru menetas akan segera mencari tempat yang lembab dimana mereka dapat mulai makan pada material organik yang membusuk. Pada tahap ini larva muda akan sangat rentan terhadap pengaruh faktor eksternal, termasuk di antaranya terhadap suhu, tekanan oksigen yang rendah, jamur, kandungan air, dan bahan beracun. Ketahanannya terhadap faktor-faktor tersebut akan meningkat setelah berumur sekitar 1 minggu (berukuran sekitar 5-10 mg). Setelah berumur 10 hari, larva-larva ini akan mampu bersaing dengan lainnya yang lebih tua dalam inkubator pengembangbiakan. Setelah menetas, mulai dari fase larva hingga mencapai tahap prepupa, BSF mampu mereduki hingga kurang lebih $55 \%$ sampah yang diberikan. Selama masa pertumbuhannya larva BSF mengalami 5 (lima) fase pergantian kulit (instar) dengan perubahan warna dari putih krem sampai dengan berwarna cokelat kehitaman pada instar terakhir (Popa dan green, 2012). Dalam kondisi ideal larva BSF akan mencapai fase prepupa dan ukuran maksimum pada hari ke-14 setelah menetas, namun pada kondisi iklim tertentu bisa berlangsung hingga hari ke-30. Beberapa kondisi non ideal yang dapat menghambat pertumbuhan larva BSF antara lain suhu yang tidak optimal, kualitas makanan yang rendah nutrien, kelembaban udara yang kurang, dan adanya zat kimia yang tidak cocok bagi larva. Pada kondisi normal larva BSF dewasa berukuran rata- rata $16-18 \mathrm{~mm}$ dengan berat antara 150-200 mg. Bahkan dalam beberapa kejadian, larva dewasa dapat mencapai ukuran 1 inci $(27 \mathrm{~mm})$ dengan berat sampai dengan $430 \mathrm{mg}$. Larva BSF membutuhkan material organik mudah terurai sebagai makanannya seperti kompos, sampah, kotoran, bangkai hewan, sayuran dan buah-buahan busuk. Larva BSF lebih aktif mengurai sisa atau sampah yang diberikan dalam keadaan mulai membusuk. Hal ini membuat sampah yang di dalamnya terdapat banyak larva BSF tidak mengeluarkan bau tidak sedap yang terlalu mencolok.

c. Fase Pupa. Setelah berganti kulit hingga instar yang keenam, larva BSF akan memiliki kulit yang lebih keras daripada kulit sebelumnya, yang disebut sebagai puparium dimana larva mulai memasuki fase prepupa. Pada tahap ini, prepupa akan mulai bermigrasi untuk mencari tempat yang lebih kering dan gelap, sebelum mulai berubah menjadi kepompong. Pupa berukuran kira-kira dua pertiga dari prepupa dan merupakan tahap dimana BSF dalam keadaan pasif dan diam, serta memiliki tekstur kasar berwarna cokelat kehitaman. Selama masa perubahan larva menjadi pupa, bagian mulut BSF yang disebut labrum akan membengkok ke bawah seperti paruh elang, yang kemudian berfungsi sebagai kait bagi kepompong. Proses metamorfosis pupa menjadi BSF dewasa berlangsung dalam kurun waktu antara sepuluh hari sampai dengan beberapa bulan tergantung kondisi suhu lingkungan.(Leanza, 2017, hlm. 6-7)

d. Lalat Dewasa. Panjang tubuh BSF dewasa adalah antara 12-20 mm dengan rentang sayap selebar 8-14 mm. BSF dewasa berwana hitam dengan kaki berwana putih pada bagian bawah dan memiliki antena (terdiri dari tiga segmen) dengan panjang 2 (dua) kali panjang kepalanya. Antara BSF betina dan BSF jantan memiliki tampilan yang tidak jauh berbeda, dengan 
ukuran tubuh BSF betina yang lebih besar dan ukuran ruas kedua pada perutnya yang lebih kecil dibanding pada BSF jantan. BSF dewasa berumur relatif pendek, yaitu 4-8 hari. BSF dewasa tidak membutuhkan makanan, namun memanfaatkan cadangan energi dari lemak yang tersimpan selama fase larva. Hal ini membuat lalat BSF tidak digolongkan sebagai vektor penyakit. Lalat dewasa berperan hanya untuk proses reproduksi. BSF dewasa mulai dapat kawin setelah berumur 2 hari. Setelah terjadi perkawinan, BSF betina akan menghasilkan sebanyak 300-500 butir telur dan meletakkannya di lokasi yang lembab dan gelap, seperti pada kayu lapuk.(Sipayung, 2015, hlm. 15-18). Suhu optimum bagi BSF untuk bertelur secara alami di alam adalah sekitar $27,5-37,5^{\circ} \mathrm{C}$, sedang di penangkaran terjadi pada suhu lebih dari $24,4^{\circ} \mathrm{C}$. Hasil penelitian menunjukkan kelembaban udara optimum yang baik untuk BSF betina dapat bertelur adalah antara $30-90 \%$. Hal ini dikarenakan BSF bersifat sangat mudah dehidrasi, sehingga dibutuhkan kelembaban udara yang cukup. Namun dengan tersedianya pasokan air pada sangkar penangkaran agar BSF dapat minum, kelembaban udara yang dapat ditolerir pada kondisi kurang lebih 20\%.(Bullock dkk., 2013, hlm. 4)

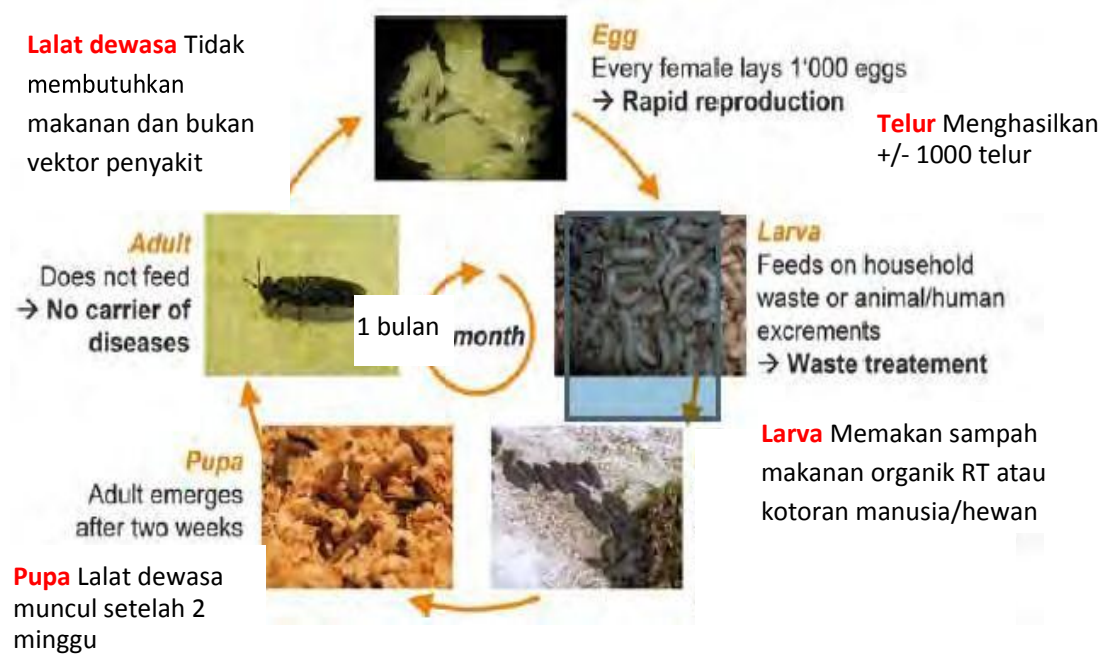

Gambar 3. Siklus Hidup BSF

Beberapa pemanfaatan yang telah dilakukan terhadap larva BSF yang telah dilakukan saat ini adalah sebagai berikut: (RACHMAWATI dkk., 2010, hlm. 30)

1. Pengelolaan kotoran hewan

2. Daur ulang sisa makanan

3. Daur ulang limbah cair domestik dan tinja

4. Composting

5. Alternatif bahan pakan ternak untuk peternakan

6. Bahan pembuatan biodiesel (RACHMAWATI dkk., 2010, hlm. 29)

Berdasarkan penelitian yang telah dilakukan Bagus Rakhman, nutrisi yang dimiliki maggot BSF ini lumayan kompleks. Maggot BSF memiliki kandungan protein maggot cukup tinggi, yaitu 44,26\% dengan kandungan lemak $29,65 \%$ sedangkan nilai asam amino, asam lemak dan mineral terkandung pada maggot juga tidak kalah dengan sumber protein lainnya, oleh sebab itu maggot BSF dapat dimanfaatkan sebagai bahan penyusunan pakan ternak (ransum). Dilihat dari umur maggot mempunyai nutrisi yang berbeda, kandungan bahan kering (BK) 
maggot BSF berhubungan positif dengan peningkatan usia yaitu $26,61 \%$ pada usia 5 hari berubah jadi $39,97 \%$ pada usia 25 hari. Nilai lemak kasar (LK) sebanyak 13,37\% pada usia 5 hari dan berubah jadi $27,50 \%$ pada usia 25 hari.(Abadi, 2020, hlm. 6)

\section{Hasil dan Pembahasan}

Permasalahan yang dihadapi warga Desa Pesing berawal disebabkan oleh kenaikan harga pakan ternak ayam \& ikan. Kenaikan harga pakan ternak ayam dan ikan ini dipicu oleh merebaknnya virus corona yang mengakibatkan pandemi global yang menggoyang kestabilan seluruh bidang termasuk pakan ternak yang sebagian besar diimpor pemerintah ataupun swasta. Untuk menghadapi permasalahan pakan yang tidak terjangkau lagi bagi pembudidaya Desa Pesing, maka dari keadaan tersebut kami membantu pembuatan pakan ternak alternatif dan inovatif dengan memanfaatkan maggot BSF yang merupakan larva dari lalat jenis black soldier fly.

Adapun rincian kegiatan yang telah terlaksana yaitu (1) Persiapan dan survey harga pakan ternak ayam dan ikan. Persiapan diawali dengan diskusi bersama kepala desa, karang taruna dan kepala dusun di Desa Pesing. Kesimpulan diskusi adalah penyuluhan dilaksanakan dua hari yakni hari pertama tentang pembuatan media maggot dan hari kedua aplikasi ataupun penyuluhan langsung ke pembudidaya ikan lele setempat. Selanjutnya kami melakukan survei harga di beberapa toko pakan terdekat dengan hasil harga pakan mengalami kenaikan berkisar 4000 sampai 6000 per kilogram. Harga pakan ayam yang awalnya 8000 naik menjadi 15.000 sedangkan pakan ikan lele yang harga awalnya 310.000 menjadi 345.000 per karung isi $30 \mathrm{~kg}$. (2) Pembelian bahan media maggot dan pembelian maggot jadi. Pembelian dilakukan pada tanggal 3 Agustus 2021. (3) Pelaksanaan penyuluhan pertama mengenai pembuatan media budidaya maggot. Penyuluhan pertama ini dilaksanakan di balai Desa Pesing pada tanggal 4 Agustus 2021 jam 08.00 dengan perwakilan peternak ayam dan ikan. Penyuluhan awal ini difokuskan pada pembuatan media maggot BSF dan tata cara pengembangbiakan dari awal sampai panen. (4) Pelaksanaan penyuluhan kedua mengenai aplikasi maggot yang telah siap pakai. Penyuluhan kedua ini dilakukan di tempat peternakan ayam dan pembudidayaan ikan lele di 3 dusun yakni, Dusun Wonorenggo, Dusun Semanding, Dusun Gempol Payung mulai jam 08.00. Penyuluhan kedua ini merupakan pemberian maggot jadi kepada masyarakat secara simbolis di setiap dusun.

Adapun materi membudidayakan larva lalat BSF pada penyuluhan pertama adalah sebagai berikut

1. Bahan dan alat yang perlu dipersiapkan

a. Dedak/bekatul $5 \mathrm{~kg}$

b. Air 1 liter

c. Gula pasir $5 \mathrm{sdm}$

d. EM4 atau bisa diganti dengan yakult 1 botol

e. Bumbu masak Royco 1 bungkus

f. 1 Ember besar dan 1 ember kecil

g. Kantong plastik bening

h. Karet/tali rafia

i. Daun pisang/kertas nasi bungkus

2. Cara pembuatan:

a. Langkah 1. Siapkan ember kecil yang sudah diisi air sebanyak 1 liter, kemudian tambahkan gula pasir sebanyak $5 \mathrm{sdm}$ dan tambahkan juga 
EM4 satu tutup botol atau diganti menggunakan Yakult sebanyak 1 botol (gunakan salah satu saja), lalu aduk merata.

b. Langkah 2. Kemudian siapkan dedak sebanyak $5 \mathrm{~kg}$, dan masukkan dalam ember besar, tambahkan 1 bungkus bumbu masak Royco agar aromanya lebih menyengat, sehingga lalat-lalat BSF datang. Aduk hingga rata sempurna.

c. Langkah 3. Campurkan larutan pertama sedikit demi sedikit kedalam campuran dedak, aduk hingga rata (usahakan adonan remah tidak terlalu basah dan tidak terlalu kering).

d. Langkah 4. Masukkan adonan dedak tersebut kedalam kantong plastik bening (jangan sampai penuh, cukup separuh saja) untuk memberikan ruang udara, karena selama proses fermentasi dedak tersebut akan mengeluarkan gas. Ikat ujung plasting dengan karet atau tali rafia. Kemudian simpan di tempat sejuk dan biarkan selama 4-5 hari. Selama itu akan terjadi proses fermentasi ditandai dengan kantong plastik yang mengembang.

e. Langkah 5. Setelah 4-5 hari plastik sudah bisa dibuka dan tuangkan kedalam ember. Tanda fermentasi yang berhasil adalah adanya aroma sepeti tape atau roti yang baru keluar dari mesin oven.

f. Langkah 6. Selanjutnya dedak hasil fermentasi ditutup dengan daun pisang atau bisa juga menggunakan kertas bungkus nasi, dengan bagian yang ada lapisan plastiknya menghadap kebawah. Agar aman dari gangguan hewan lain, tutupi ember dengan menggunakan kawat ram.

g. Aroma fermentasi inilah yang akan memancing lalat BSF untuk datang dan bertelur. Anda tinggal bersabar menunggu selama 1-3 hari, bisa lebih. Ketika datang, lalat BSF akan bertelur tapi tidak di dedaknya langsung, melainkan disekitar fermetasi dedak, bisa dipinggir ember atau di tutup ram. Setelah bertelur, biasanya 2-3 hari telur-telur tersebut akan menetas, dan bayi-bayi maggot ini dengan sendirinya akan bergerak menuju dedak fermetasi sebagai sumber maakanan dan media hidup bagi maggot lalat BSF. Dalam seminggu setelah menetas, magot-magot kecil ini sudah terlihat jelas. Memasuki umur 23 minggu maggot-maggot sudah besar dan siap untuk dipanen.

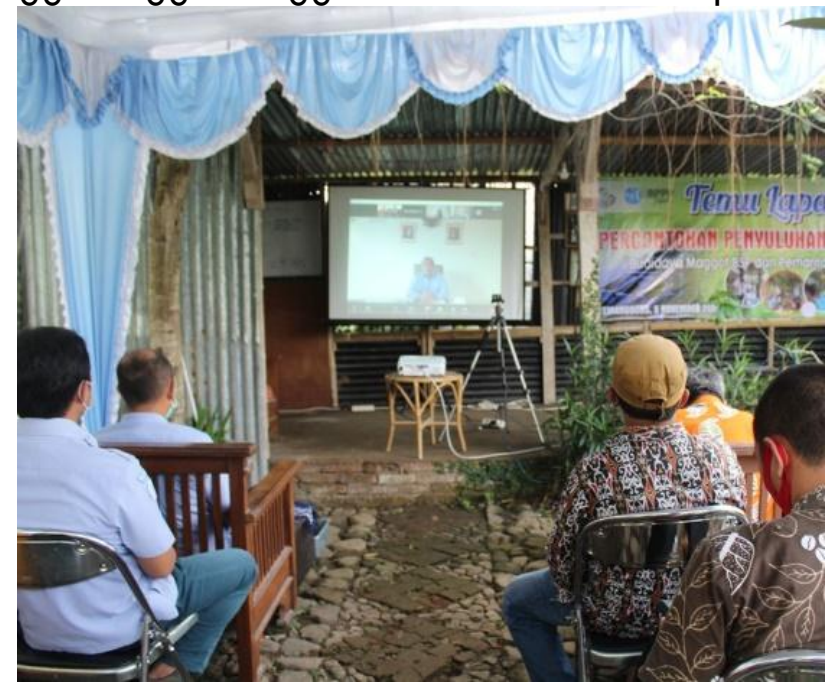

Gambar 4. Penyuluhan pembuatan media maggot 


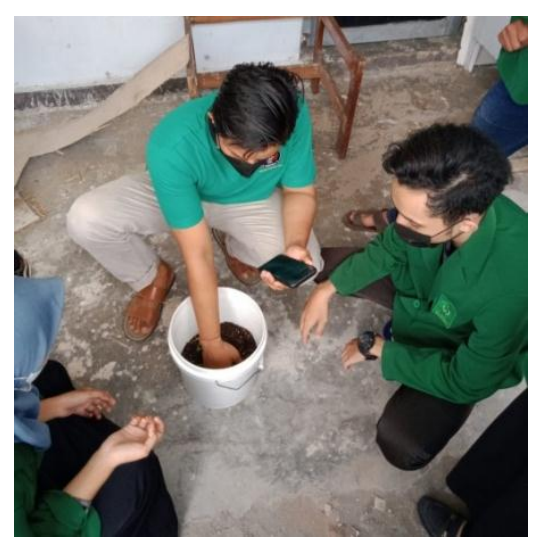

Gambar 5. Penyuluhan pembuatan media maggot

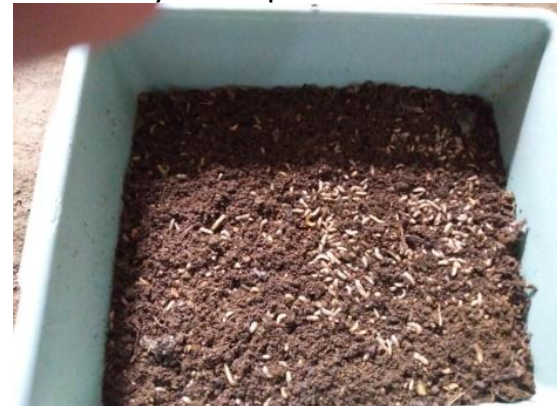

Gambar 6. Media maggot BSF

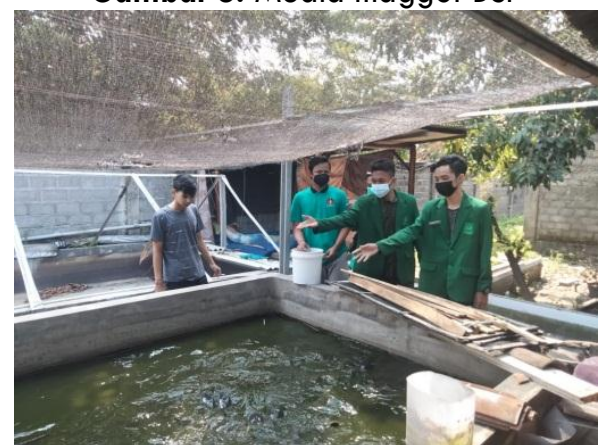

Gambar 7. Pemberian produk maggot BSF jadi

Desa Pesing secara administratif terletak di wilayah Kecamatan Purwoasri Kabupaten Kediri dengan posisi dibatasi oleh wilayah desa-desa tetangga. Di sebelah utara berbatasan dengan Desa Wonotengah. $\mathrm{Di}$ sebelah timur berbatasan dengan wilayah Desa Puhjajar. Di sebelah selatan berbatasan dengan wilayah Desa Srikaton. Sedangakan di sisi barat berbatasan dengan wilayah Desa Mranggen. Desa Pesing secara geografis terletak pada koordinat $7^{\circ} 40.3909^{\prime}$ Lintang Selatan dan $112^{\circ} 5.3547^{\prime}$ Bujur Timur.

Desa Pesing merupakan salah satu desa di Kecamatan Purwoasri wilayah Kabupaten Kediri. Topografi ketinggian dataran rendah merupakan topografi desa ini yang membujur $51 \mathrm{~m}$ di atas permukaan laut. Wilayah Desa Pesing ini memiliki luas kurang lebih $239 \mathrm{Ha}$. Wilayah Desa Pesing ini dibagi dalam beberapa peruntukan untuk mendukung beberapa bidang, seperti fasilitas umum, permukiman warga, pertanian, perkebunan, dan lainnya. Desa Pesing sendiri terbagi menjadi 5 dusun yakni Dusun Pesing, Dusun Wonorenggo, Dusun Semanding, Dusun Gempol Payung, Dusun Magersari. 


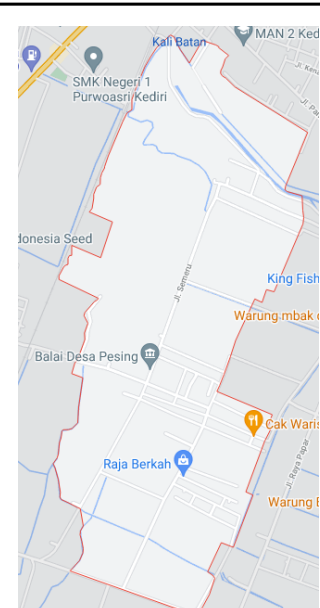

Gambar 8. Peta Desa Pesing

Dari hasil wawancara, observasi didapatkan informasi mengenai potensi dan hambatan di Desa Pesing. Desa Pesing memiliki potensi yang cukup beragam. Potensi yang teridentifikasi di desa ini antara lain terdapat pada bidang pertanian, perkebunan, dan peternakan. Pada sektor pertanian, tanah yang subur dan luas serta saluran irigasi yang memadai menjadi faktor yang sangat mendukung dalam perkembangan petani dalam mengelola sawah. Jenis tanaman yang ditanam berkutat pada padi, jagung, tebu dan sayur mayur. Untuk sektor perkebunan, terdapat pembudidayaan jambu dersono dan anggur. Pada sektor peternakan, terdapat pemain besar dan pemain kecil di desa ini dengan jenis ternak ayam, kambing, ikan lele dan ikan konsumsi lainnya.

Hambatan yang dirasakan peternak ayam dan ikan konsumsi di Desa Pesing adalah kenaikan harga pakan ternak. Kenaikan pakan ternak ini dipicu oleh kelangkaan stok akibat distribusi yang terhambat oleh aturan pembatasan akibat pandemi COVID-19. Tentu saja pandemi virus corona ini menjadi pemicu goncangan ekonomi yang tengah dicoba untuk ditangani pemerintah. Namun dengan pandemi yang terus bergulir mengakibatkan harga komoditi termasuk pakan ternak melambung naik. Disinyalir hal ini terjadi akibat pakan ternak juga bersumber dari import barang di luar negeri.(Yamali \& Putri, 2020, hlm. 384) Kenaikan harga yang terus menerus ini mengancam keberlangsungan usaha peternak setempat. Untuk menghadapi permasalahan ini maka diperlukan solusi untuk menggantikan pakan ternak dengan harga yang lebih terjangkau oleh masyarakat. Maka dari itu, kami mengajukan solusi dengan pembudididayaan maggot lalat BSF sebagai pengganti pakan ternak ataupun menjadi pakan pendukung bermutu tinggi. Pelatihan itu sendiri adalah serangkaian kegiatan belajar yang meminimalisir penyampaian teori dan lebih memperbanyak jam praktek secara langsung, dengan menggunakan berbagai metode yang bertujuan untuk meningkatkan salah satu skill yang dimiliki oleh individu maupun organisasi.(Santoso, 2013, hlm. 14) Dengan solusi ini diharapkan biaya yang diperlukan untuk membeli pakan ternak bisa dikurangi sehingga peternak di Desa Pesing dapat meningkatkan keuntungan dengan tetap menjaga kualitas produk.

Budidaya ini hanya memerlukan modal awal kecil yakni mulai 30 ribuan. Dengan modal 30 ribuan untuk membuat media pembudidayaan larva lalat BSF ini, pembudidaya dapat memanen maggot untuk dijadikan pakan ternak dengan kualitas tinggi karena mengandung protein sampai $45 \%$ dan nutrisi baik lainnya. Selain itu, pembudidayaan maggot dengan taraf yang lebih besar lagi dapat berpotensi sebagai peluang usaha karena permintaan pasar dengan larva / magot ini cukup tinggi. Untuk masalah makanan bagi maggot, sampah organik 
rumah tangga dapat diberikan sekaligus untuk mendaur ulang sampah organik yang biasanya hanya dibuang percuma.

Secara umum maka, manfaat pembudidayaan maggot atau larva lalat black soldier fly ini adalah sebagai berikut:

1. Dapat mendegradasi sampah organik menjadi nutrisi untuk pertumbuhannya

2. Dapat mengkonversi sampah organik menjadi kompos dengan kandungan penyubur yang tinggi

3. Dapat mengontrol bau dan hama, serta dapat mengurangi emisi gas rumah kaca pada saat proses dekomposisi sampah

4. Tubuhnya mengandung zat kitin dan protein yang cukup tinggi yang dapat digunakan sebagai pakan ternak

5. Kandungan lemak yang tinggi pada tubuh larva BSF dapat dimanfaatkan sebagai bahan biofuel.

\section{PENUTUP}

Penyuluhan mengenai pembudidayaan larva/ maggot lalat black soldier fly (BSF) ini merupakan salah satu bentuk pengabdian kepada masyarakat Desa Pesing Kecamatan Purwoasri Kabupaten Kediri. Pendekatan dalam pengabdian masyarakat ini termasuk kedalam pendekatan Participatory Action Research karena dilaksanakan secara partisipatif di antara masyarakat warga dalam suatu komunitas atau lingkup sosial yang lebih luas untuk mendorong terjadinya aksi-aksi transformatif (perubahan kondisi hidup yang lebih baik). Aksi transformatif ini berupa pemanfaatan maggot BSF sebagai pengganti ataupun pakan ternak pendukung yang berkualitas tinggi untuk menghadapi permasalahan kenaikan harga pakan ternak yang menimpa peterkan di Desa Pesing. Kenaikan harga komoditi pakan ternak yang dipicu oleh pandemi virus corona menjadikan produksi ayam dan ikan konsumsi menurun. Dengan alternatif pakan ternak berupa maggot BSF ini diharapkan kuantitas maupun kualitas produksi ayam dan ikan konsumsi oleh peternak di Desa Pesing dapat meningkat lebih baik lagi. Di samping itu, tidak boleh dilupakan bahawa selain sebagai pakan ternak, maggot BSF merupakan solusi penanganan sampah organik rumah tangga dan peluang bisnis yang menjanjikan.

\section{E. UCAPAN TERIMA KASIH}

Ucapan terima kasih penulis sampaikan kepada seluruh pihak yag telah berperan serta baik secara langsung di lapangan maupun tidak langsung dalam penyelenggaraan penyuluhan pembudidayaan maggot BSF kepada: 1) Lembaga Penelitian dan Pengabdian Masyarakat, Institut Agama Islam Negeri Kediri; 2) Seluruh teman mahasiswa yang telah membantu saya selama $\mathrm{KKN}_{i ;}$ 3) lbu Oktotina Mayline A.H, S.E selaku Kepala Desa Pesing; 4) Kedua orang tua saya yang menjadi support system terbaik; 5) Seluruh warga masyarakat Desa Pesing yang telah berpartisipasi dalam kegiatan pengabdian masyarakat dalam bentuk penyuluhan pembudidayaan maggot BSF.

\section{F. DAFTAR PUSTAKA.}

Abadi, B. R. (2020). Pengaruh Media Terhadap Pertumbuhan dan Kandungan Abu pada Maggot Black Soldier Fly (Hermetia Illucens) [Tesis, University of Muhammadiyah Malang]. https://eprints.umm.ac.id/60952/

Alvarez, L. (2012). The Role of Black Soldier Fly, Hermetia illucens (L.) (Diptera: Stratiomyidae) in Sustainable Waste Management in Northern Climates [Tesis, University of Windsor]. https://scholar.uwindsor.ca/etd/402 
Bringle, R. G., Hatcher, J. A., \& Mclntosh, R. E. (2006). Analyzing Norton's Typology of Service Paradigma and Integrity. Michigan Journal of Community Service Learning, MJCSL 13-1 10/11/06.

Bullock, N., Chappin, E., \& Evans, A. (2013). The Black Soldier Fly - How to Guide. University of Windsor.

Diener, S., Studt Solano, N. M., Roa Gutiérrez, F., Zurbrügg, C., \& Tockner, K. (2011). Biological Treatment of Municipal Organic Waste using Black Soldier Fly Larvae. Waste and Biomass Valorization, 2(4), 357-363. https://doi.org/10.1007/s1 2649-01 1-9079-1

Direktorat Riset Pengabdian kepada Masyarakat Universitas Indonesia. (2011). Panduan Pengajuan Proposal Hibah Pengabdian kepada Masyarakat Universitas Indonesia. Universitas Indonesia.

Guritno, T. (2021, Maret 9). 6.389 Kasus Baru Covid-19 Tersebar di 33 Provinsi, Jawa Barat Terbanyak dengan 1.787 Kasus. KOMPAS.com. https://nasional.kompas.com/read/2021/03/09/18251891/6389-kasusbaru-covid-19-tersebar-di-33-provinsi-jawa-barat-terbanyak-dengan

Hem, S. (2011). Project FISH-DIVA : Maggot-Bioconversion research program in Indonesia concept of new food resources results and applications 20052011 : Final report. IRD, 1(1), 44 multigr. +47 p. d'annexes.

Holmes, L. A., Vanlaerhoven, S. L., \& Tomberlin, J. K. (2012). Relative Humidity Effects on the Life History of Hermetia illucens (Diptera: Stratiomyidae). Environmental Entomology, 41(4), 971-978. https://doi.org/10.1603/EN1 2054

Huang dkk., C. (2020). Clinical Features of Patients Infected with 2019 Novel Coronavirus in Wuhan, China. Lancet (London, England), 395(10223).

IAIN Kediri, L. P. dan P. M. (LPPM). (2021). Buku Pedoman Kuliah Kerja Nyata dari Rumah (KKN-DR) IAIN Kediri Tahun 2021. LPPM IAIN Kediri.

Leanza, M. (2017). Proses Pengolahan Sampah Organik dengan Black Soldier Fly (BSF). Eawag.

Maharani, T. (2021, Agustus 26). UPDATE 26 Agustus: Bertambah 30.099, Kasus Sembuh Covid-19 Jadi 3.669.966. KOMPAS.com. https://nasional.kompas.com/read/2021/08/26/17331021/update-26agustus-bertambah-30099-kasus-sembuh-covid-19-jadi-3669966

RACHMAWATI, Buchori, D., Hidayat, P., Hem, S., \& Fahmi, M. R. (2010). Perkembangan dan Kandungan Nutrisi Larva Hermetia illucens (Linnaeus) (Diptera: Stratiomyidae) pada Bungkil Kelapa Sawit. Jurnal Entomologi Indonesia, 7(1), 28-28.

Santoso, B. (2013). Pendidikan Islam. Islamadina, $12(01), 42159$.

Satriya P. K.W, W. H. (2013). LKP: Rancang Bangun Sistem Informasi Pengelolaan Data Pengabdian Masyarakat Pada Bagian Penelitian Dan Pengabdian Masyarakat Stikom Surabaya [Tesis, STIKOM Surabaya]. https://repository.dinamika.ac.id/id/eprint/29/

Shodiq, A. R. A. (2013). Sistem informasi penelitian dan pengabdian kepada masyarakat sesuai standar BAN-PT [Tesis, Universitas Islam Negeri Maulana Malik Ibrahim]. http://etheses.uin-malang.ac.id/7666/

Sipayung, P. Y. E. (2015). Pemanfaatan Larva Black Soldier Fly (Hermetiaillucens) sebagai Salah Satu Teknologi Reduksi Sampah di Daerah Perkotaan [Tesis, Institut Technology Sepuluh Nopember]. https://repository.its.ac.id/59907/

Yamali, F. R., \& Putri, R. N. (2020). Dampak Covid-19 Terhadap Ekonomi Indonesia. Ekonomis: Journal of Economics and Business, 4(2), 384-388. https://doi.org/10.33087/ekonomis.v4i2.179 